\title{
Differentiation syndrome in acute promyelocytic leukemia: pathogenesis and risk factors
}

\section{Síndrome da diferenciação na leucemia promielocítica aguda: patogênese e fatores de risco}

Eduardo M. Rego

Bárbara A. A. Santana-Lemos

Mirela B. Tamarozzi

\begin{abstract}
Differentiation syndrome is a treatment complication which can occur in acute promyelocytic leukemia (APL) patients treated with all-trans retinoic acid (ATRA) or arsenic trioxide (ATO), which is characterized by enhanced leukocyte transmigration. Several cellular and molecular mechanisms participate in differentiation syndrome development. This review discusses the changes in expression of adhesion molecules induced during ATRA and ATO treatments and their possible implications in the pathogenesis of this potentially fatal complication. Rev. bras. hematol. hemoter. 2008;30(Supl. 2):33-36.
\end{abstract}

Key words: Acute promyelocytic leukemia; adhesion molecules; retinoids; arsenic trioxide.
The reciprocal translocation involving chromosomes 15 and $17[\mathrm{t}(15 ; 17)(\mathrm{q} 22 ; \mathrm{q} 21)]$ is associated with acute promyelocytic leukemia (APL) and leads to the fusion of the retinoic acid receptor $\alpha(\mathrm{RAR} \alpha)$ and promyelocytic leukemia (PML) genes thus generating the PML/RAR $\alpha$ hybrid gene. ${ }^{1}$ The use of all-trans retinoic acid (ATRA) and anthracyclinebased chemotherapy represents the mainstay in treatment of APL, inducing complete hematological and molecular remission in a high proportion of patients. ${ }^{2-4}$ ATRA induces the malignant cells to differentiate into phenotypically mature myeloid cells, and prompt resolution of the characteristic coagulopathy of APL. In vitro, the differentiation process induced by ATRA has been associated with increased expression of integrins, cytokine release, and changes in cellular rheology. ${ }^{5-8}$ More recently, arsenic trioxide (ATO) has been included in the armamentarium of active drugs in APL, being perhaps the most active single agent. ${ }^{9}$ ATO at lower doses induces myeloid differentiation, whereas in higher doses it induces apoptosis.

Although ATRA and ATO are well tolerated, approximately one fourth of the patients develop the differentiation syndrome (DS), formerly known as Retinoid Acid Syndrome. DS was first described by Frankel et al (1992) ${ }^{10}$ who detected this syndrome in nine of $35(25 \%)$ newly diagnosed APL patients. Symptoms occurred after 2 to 21 days of treatment and were generally associated with increasing white blood cell (WBC) count and combined fever, weight gain, dyspnea, pleural effusion, and pulmonary infiltrates on chest radiograph and, in some patients, renal failure, hypotension, and pericardial effusion. Six percent to $27 \%$ of APL patients develop DS, and mortality rates range from $1 \%$ to $7 \%{ }^{11-13}$ Our group analyzed $71 \mathrm{APL}$ patients treated with ATRA + anthracycline and observed a DS incidence of $11.26 \%$, with an average time for syndrome development of 11.5 days after starting ATRA treatment and a mortality rate of $12.5 \%{ }^{14}$ Taken together, the data in literature reinforce the importance of early diagnosis, since DS responds well to dexamethasone treatment $(10 \mathrm{mg}$ twice daily for at least 3 days). Interestingly, the results from the European APL Group trials suggested that, besides corticosteroids, chemotherapy concomitant to ATRA reduced the incidence of the syndrome, although there was

Hematology Division, Department of Internal Medicine, Medical School of Ribeirão Preto, University of São Paulo

Correspondence: Eduardo Magalhães Rego

Medical School of Ribeirão Preto, University of São Paulo

Hematology Division, Department of Internal Medicine, Medical School of Ribeirão Preto

Av. Bandeirantes 3900

14049-900 - Ribeirão Preto-SP - Brazil

Phone: 55-16-3602-2888; Fax: 55-16-3633-6645

E-mail:emrego@hcrp.fmrp.usp.br 


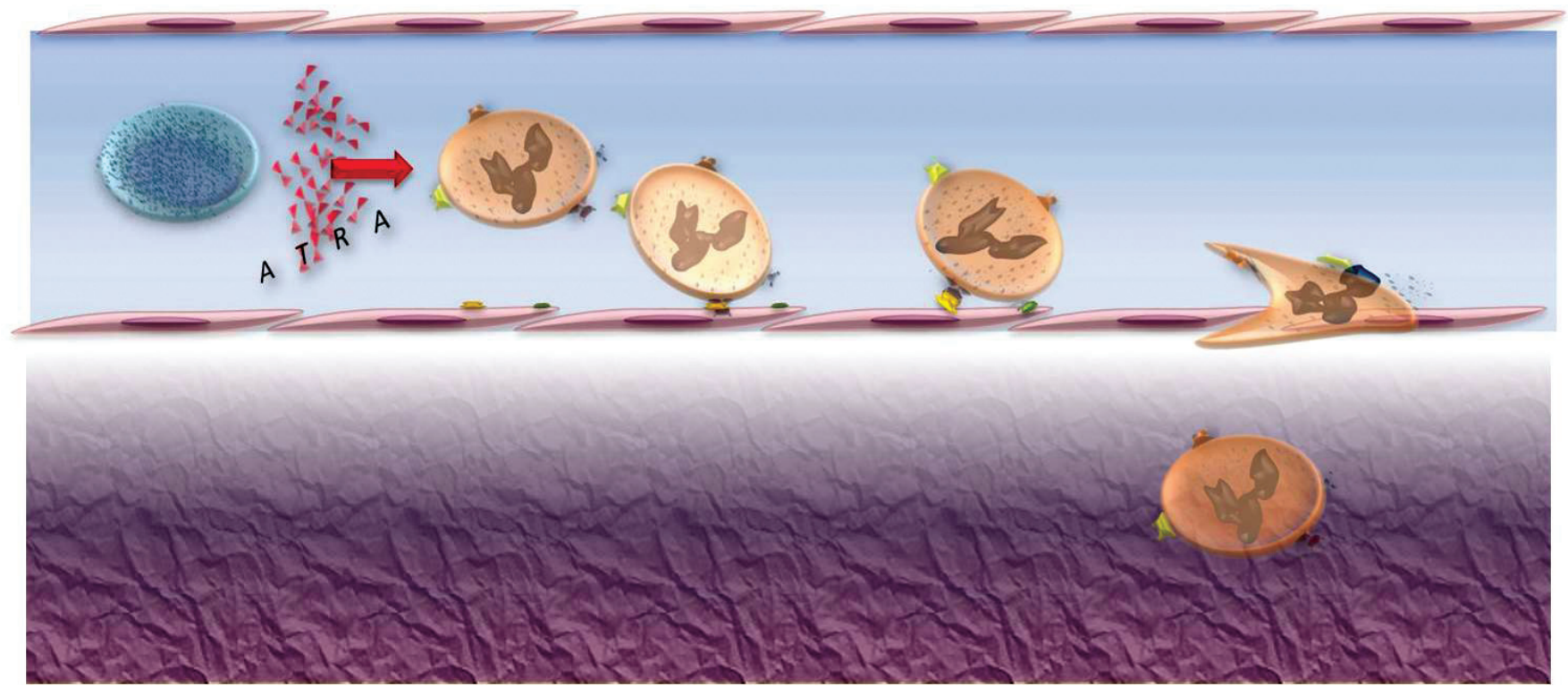

Figure 1. Cellular and molecular mechanisms participate in DS development.

ATRA treatment induces increase in the expression of adhesion molecules such as CD11b, CD18 and ICAM-1, which increase the adhesion of myeloid to endothelial cells, thus facilitating the stable arrest and transmigration.

no clear reduction in the related mortality rate. ${ }^{15}$ As mentioned above, DS is also seen with ATO treatment. Twenty-three percent of the APL patients in the US multicenter trial ${ }^{16}$ developed DS. All of these patients also had leukocytosis and were treated with dexamethasone without any deaths and without interruptions in the administration of arsenic trioxide.

Several cellular and molecular mechanisms participate in DS development (Figure 1). ATRA induces a variety of effects in APL cells in vitro, including increased production of interleukin-1 beta (IL-1 $\beta),{ }^{6,17}$ IL-8, ${ }^{6}$ receptors for granulocyte colony-stimulating factor $(\mathrm{G}-\mathrm{CSF})^{18}$ and granulocyte-macrophage colony-stimulating factor (GM$\mathrm{CSF}) .{ }^{19}$ Changes in the expression of cell-surface integrins, such as LFA-1 (CD11a/CD18) and Mac-1(CD11b/CD18), also were demonstrated by different authors. ${ }^{5,20-22}$ Several clinical features of DS seem to be related to these observations, in particular, fever, fluid retention, and the migration of differentiating myeloid cells into extravascular tissues. ${ }^{10}$ Extravascular migration of myeloid cells may be partly related to upregulated integrin expression, which could increase adhesion of these cells to vascular endothelium, thereby facilitating their extravasation. ${ }^{20,23-24}$ Nevertheless, Brown et al. (1999) ${ }^{25}$ have demonstrated that ATRA induced rolling of NB4 cells (an APL cell line) on endothelium through the modulation of E-selectin, without the participation of $\alpha_{4}$ integrin and P-selectin. In addition to these molecules, intercellular adhesion molecule-1 (ICAM-1, CD54) may further contribute to DS development since adhesion of leukocytes to endothelial cells is an essential prerequisite for stable arrest and transmigration of neutrophils. In fact, levels of soluble CD54 increase in the plasma of APL patients and decrease after the APL is cured. ${ }^{5}$

Recently, our group demonstrated a significant increase in the expression of CD $11 \mathrm{~b}$ and ICAM-1 in ATRAtreated NB4 cells, while in APL primary cells, in addition to these two markers, CD18 was also up-regulated by ATRA. ${ }^{8}$ In the same study, ATO up-regulated ICAM-1 in NB4 cells both at 0.1 and $1 \mu \mathrm{M}$ concentration. G-CSF treatment upregulated $\mathrm{CD} 11 \mathrm{~b}$ expression and potentiated ATRA-induced CD18 and CD11b expression on APL primary cells. Importantly, we did not detect synergism between ATRA and ATO in the upregulation of these molecules. This observation is relevant in face of the recent results of clinical trials using the combination of ATO and ATRA as front line therapy for APL. ${ }^{26}$

The increase in CD11b, CD18 and CD54 expression was accompanied by a higher adhesion to Matrigel and to pulmonary endothelium, and was blocked by pre-incubation with dexamethasone, anti-CD54 or anti-CD18. To test the role of these adhesion molecules in vivo, CD54 or CD18 knock out mice and their wild-type controls were injected with NB4 cells and treated IP with ATRA. After sacrifice, MPO activity in the lungs was determined by colorimetric assay. These results suggest that both leukocyte and endothelial adhesion molecules are essential for DS development.

Gao et al (2007) ${ }^{27}$ demonstrated that in addition to IL$1 \beta$ and IL-8, ATRA treatment could induce the expressions of IFN- $\gamma$ in APL patient blast cells. By using human umbilical cord endothelial cells (HUVECs), and human lung microvascular endothelial cells (HLMVECs), they observed that low doses of IFN- $\gamma$ and IL-1 $\beta$ could synergistically 
iinduce apoptosis in endothelial cells with upregulated expression of CD38 antigen. Using leukemia cells NB4 and HL60 as a model, they presented evidence that CD38 expression promotes the binding interactions between leukemia cells and endothelial cells.

Several features have been investigated as prognostic for DS development. Fenaux et al. (1992) ${ }^{28}$ described that the number of leukocytes at diagnosis correlated with DS development. However, De Botton et al. (1998) ${ }^{15}$ analyzing a larger cohort of patients did not detect significative differences on leukocyte counts at diagnosis between patients that developed or not DS. It is interesting to note that Vahdat et al. (1999) ${ }^{11}$ also did not find correlation between the number of leukocytes and DS development but, on the contrary, the maximum value of this number after the introduction of ATRA presented important association. In addition, Tallman et al. $(2000)^{3}$ had affirmed that patients with microgranular variant M3v of APL appear to be protected from the syndrome, but these findings had not been confirmed in posterior studies. ${ }^{14}$

Considering the relevance of ICAM1 in leukocyte infiltration and the effect of ATRA and ATO on its expression, we decided to analyze the role of ICAM1 polymorphisms in DS development. We included PECAM-1 (platelet-endothelial cell adhesion molecule-1) polymorphisms since it is constitutively expressed by most circulating leukocytes, platelets and endothelial cells, and both adhesion molecules are involved in endothelium integrity and extravasation of cells from the blood compartment into the vessel and underlying tissue..$^{29} \mathrm{We}$ analyzed $127 \mathrm{APL}$ patients of whom 23 developed DS. Only patients with respiratory distress accompanied by pulmonary infiltrates were analyzed. Regarding age, gender, WBC counts, hemoglobin and platelets values, no predictive factor of DS development in APL patients could be found. Considering genetic variations in adhesion molecules ICAM-1 and PECAM-1 we detected no significant association between ICAM-1 G241R or PECAM-1 L125V polymorphisms and DS. On the other hand, the AA genotype at codon 469 of ICAM-1 was significantly associated to DS in APL patients. ${ }^{30}$ The $469 \mathrm{E} /$ $\mathrm{K}$ polymorphism in exon 6 results in a change from glutamic acid to lysine in Ig-like domain 5 of ICAM-1, which is thought to affect interactions with LFA-1 and adhesion of B-cells. The functional effect of this polymorphism is still unclear, but it may influence disease susceptibility.

In conclusion, DS is a multifactorial process and the activation of adhesion molecules by ATRA and ATO are triggering events. Genetic determinants, such as ICAM-1 polymorphisms, may play a role in its pathogenesis and larger multicentric studies are necessary to establish the value these markers as risk factors in DS development.

\section{Resumo}

A síndrome da diferenciação (DS) é um efeito colateral que pode ocorrer em pacientes com leucemia promielocítica aguda (APL) tratados com ácido all-trans-retinóico (ATRA) ou trióxido de arsênico (ATO), sendo caracterizada pelo aumento da transmigração de leucócitos. Vários mecanismos celulares e moleculares participam no desenvolvimento da DS. Esta revisão discute as mudanças na expressão de moléculas de adesão induzidas durante o tratamento com ATRA e ATO e possiveis implicações na patogênese desta complicação potencialmente fatal. Rev. bras. hematol. hemoter. 2008;30(Supl. 2):33-36.

Palavras-chave: Leucemia promielocítica aguda; moléculas de adesão; retinóides; trióxido de arsênico.

\section{References}

1. Piazza F, Gurrieri C, Pandolfi PP. The theory of APL. Oncogene. 2001;20(49):7216-22.

2. Sanz MA, Martín G, Rayón C, Esteve J, González M, Díaz-Mediavilla $\mathrm{J}$, et al. A modified AIDA protocol with anthracycline-based consolidation results in high antileukemic efficacy and reduced toxicity in newly diagnosed PML/RARalpha-positive acute promyelocytic leukemia. PETHEMA Group. Blood. 1999;94(9):3015.

3. Tallman MS, Andersen JW, Schiffer CA, Appelbaum FR, Feusner $\mathrm{JH}$, Ogden A, et al. Clinical description of 44 patients with acute promyelocytic leukemia who developed the retinoic acid syndrome. Blood. 2000;95(1):90-5.

4. Fenaux P, Chastang C, Chevret S, Sanz M, Dombret H, Archimbaud E, et al. A randomized comparison of all transretinoic acid (ATRA) followed by chemotherapy and ATRA plus chemotherapy and the role of maintenance therapy in newly diagnosed acute promyelocytic leukemia. The European APL Group. Blood. 1999;94(4):1192-200.

5. Hsu HC, Tsai WH, Chen PG, Hsu ML, Ho CK, Wang SY. In vitro effect of granulocyte colony-stimulating factor and all-trans retinoic acid on the expression of inflammatory cytokines and adhesion molecules in acute promyelocytic leukemic cells. Eur J Haematol. 1999;63(1):11-18.

6. Dubois C, Schlageter MH, de Gentile A, et al. Modulation of IL-8, IL-1 beta, and G-CSF secretion by all-trans retinoic acid in acute promyelocytic leukemia. Leukemia. 1994;8(10):1750-7.

7. Grande A, Manfredini R, Tagliafico E, Balestri R, Pizzanelli M, Papa $\mathrm{S}$, et al. All-trans-retinoic acid induces simultaneously granulocytic differentiation and expression of inflammatory cytokines in HL-60 cells. Exp Hematol. 1995;23(2):117-25.

8. Cunha De Santis G, Tamarozzi MB, Souza RB, Moreno SE, Secco $\mathrm{D}$, Garcia AB, et al. Adhesion molecules and Differentiation Syndrome: phenotypic and functional analysis of the effect of ATRA, As2O3, phenylbutyrate, and G-CSF in acute promyelocytic leukemia. Haematologica. 2007;92(12):1615-162.

9. Douer D. ATO: the forefront of APL treatment? Blood. 2006; 107:2588-9.

10. Frankel SR, Eardley A, Lauwers G, Weiss M, Warrell R. The "retinoic acid syndrome" in acute promyelocytic leukemia. Ann Intern Med. 1992;117(4):292-6.

11. Vahdat L, Maslak P, Miller WH Jr, Eardley A, Heller G, Scheinberg DA, et al. Early mortality and the retinoic acid syndrome in acute promyelocytic leukemia: impact of leukocytosis, low-dose chemotherapy, PMN/RAR-alpha isoform, and CD13 expression in patients treated with all-trans retinoic acid. Blood. 1994; 84(11):3843-9. 
12. Tallman MS, Andersen JW, Schiffer CA, Appelbaum FR, Feusner $\mathrm{JH}$, Ogden A, et al. All-trans-retinoic acid in acute promyelocytic leukemia. New Engl J Med. 1997;337(15):1021-8.

13. De Botton S, Chevret S, Coiteux V, Dombret H, Sanz M, San Miguel $\mathrm{J}$ et al. Early onset of chemotherapy can reduce the incidence of ATRA syndrome in newly diagnosed acute promyelocytic leukemia (APL) with low white blood cell counts: results from APL 93 trial. Leukemia. 2003;17(2):339-42.

14. Santos FLS, Dore AI, Lima ASG, Garcia AB, Zago MA, Rizzatti EG et al. Hematological features and expression profile of myeloid antigens of acute promyelocytic leukemia patients. analysis of prognostic factors for development of the retinoic acid syndrome. Rev. Assoc. Med. Bras. 2004;50(3):286-92.

15. De Botton S, Dombret H, Sanz M, Miguel JS, Caillot D, Zittoun R, et al. Incidence, clinical features, and outcome of all trans-retinoic acid syndrome in 413 cases of newly diagnosed acute promyelocytic leukemia. The European APL Group. Blood. 1998;92(8):2712-8.

16. Soignet SL, Frankel SR, Douer D, Tallman MS, Kantarjian H, Calleja $\mathrm{E}$ et al. United States multicenter study of arsenic trioxide in relapsed acute promyelocytic leukemia. J Clin Oncol. 2001; 19(18):3852-60.

17. Matikainen S, Tapiovaara H, Vaheri A, et al. Activation of interleukin-1 beta gene expression during retinoic acid-induced granulocytic differentiation of promyelocytic leukemia cells. Cell Growth Differ. 1994;5(9):975-82.

18. Tkatch LS, Rubin KA, Ziegler SF, Tweardy DJ. Modulation of human G-CSF receptor mRNA and protein in normal and leukemic myeloid cells by G-CSF and retinoic acid. J Leukoc Biol. 1995; 57(6):964-71

19. de Gentile A, Toubert M-E, Dubois C, et al. Induction of highaffinity GM-CSF receptors during all-trans-retinoic acid treatment of acute promyelocytic leukemia. Leukemia. 1994;8(10):1758-62.

20. Di Noto R, Schiavone EM, Ferrara F, Manzo C, Lo Pardo C, Del Vecchio L. All-trans retinoic acid promotes a differential regulation of adhesion molecules on acute myeloid leukaemia blast cells. $\mathrm{Br} \mathrm{J}$ Haematol. 1994,88(2):247-55.

21. Zang C, Liu H, Ries C, Ismair MG, Petrides PE. Enhanced migration of the acute promyelocytic leukemia cell line NB4 under in vitro conditions during short-term all-trans-retinoic acid treatment. J Cancer Res Clin Oncol. 2000;126(1):33-40.

22. Barber N, Belov L, Christopherson RI. All-trans retinoic acid induces different immunophenotypic changes on human HL60 and NB4 myeloid leukaemias. Leuk Res. 2008;32(2):315-22.
23. Adams DH, Shaw S. Leukocyte-endothelial interactions and regulation of leukocyte migration. Lancet. 1994;343(8901):831-6.

24. Huber AR, Kundel SL, Todd RF, et al. Regulation of transendothelial neutrophil migration by endogenous interleukin-8. Science. 1991; 254(5028):99-102.

25. Brown DC, Tsuji H, Larson RS. All-trans retinoic acid regulates adhesion mechanism and transmigration of the acute promyelocytic leukaemia cell line NB-4 under physiologic flow. Br J Haematol. 1999;107(1):86-98.

26. Shen ZX, Shi ZZ, Fang J, Gu BW, Li JM, Zhu YM, et al. All-trans retinoic acid/As2O3 combination yields a high quality remission and survival in newly diagnosed acute promyelocytic leukemia. Proc Natl Acad Sci USA. 2004;101(15):5328-35.

27. Gao Y, Camacho LH, Mehta K. Retinoic acid-induced CD38 antigen promotes leukemia cells attachment and interferon-gamma/ interleukin-1beta-dependent apoptosis of endothelial cells: implications in the etiology of retinoic acid syndrome. Leuk Res. 2007;31(4):455-63.

28. Fenaux P, Castaigne S, Chomienne C, Dombret H, Degos L. All trans retinoic acid treatment for patients with acute promyelocytic leukemia. Leukemia. 1992;6 (Suppl 1):64-6.

29. Hordijk PL. Endothelial signaling events during leukocyte transmigration. FEBS J. 2006;273(19):4408-15.

30. Dore AI, Santana-Lemos BAA, Coser VM, Santos FLS, Dalmazzo LF, Lima ASG, Jacomo RH et al. The association of ICAM-1 Exon 6 (E469K) but not of ICAM-1 Exon 4 (G241R) and PECAM-1 Exon $3(\mathrm{~L} 125 \mathrm{~V})$ polymorphisms with the development of differentiation syndrome in acute promyelocytic leukemia. J Leukoc Biol. 2007;82(5):1340-43.

O tema apresentado constou do programa do Encontro AIBE. Avaliadores: Professores Ângelo Maiolino, Cármino Antonio de Souza e Marcio Nucci.

Publicado após concordância do editor.

Conflito de interesse: não declarado.

Recebido: 09/05/2008

Aceito: 13/05/2008 